\title{
IMPROVING STUDENTS UNDERSTANDING ABOUT THE VALUE OF PLACE THROUGH DEMONSTRATION METHOD OF SECOND GRADE STUDENTS IN SD NEGERI 28 PASAR GOMPONG KECAMATAN LENGAYANG KABUPATEN PESISIR SELATAN
}

\author{
HEPPI LINDA
}

Volume 1 Nomor 1

JIPS ISSN: 2579-5449

\begin{abstract}
Education is a way of establishing human ability to use their rational / thoughtfulness as an answer in dealing with various problems that arise in the future. One of the goals of education is to improve the quality of human resources. With good education we will easily follow the development of the times in the future. The research objective of this study was to determine whether the use of methods of demonstration can improve understanding of place value in the second grade students of SD Negeri 28 Gompong Market Lengayang District of South Coastal District. The purpose of this learning improvement research was to determine whether the use of methods of demonstration can improve understanding of place value in the second grade students of SD Negeri 28

Gompong Market Lengayang District of South Coastal District.

This study

on peningkata $\mathrm{n}$ understanding of the value of using the demonstration carried out through several tahapan.Tahapan in question is planning,observation, and reflection.

Results from this study is appears 18 students have been able to understand the material value of the place through the method of demonstration and almost all of the students has increased very significantly from cycle 1 to cycle 2. It is proved that the use of highly precise method of demonstration to enhance students' skills in particular about place value. A significant increase starting from pre cycle (55\%), then on cycle 1 increased to $65 \%$ and cycle 2 increased to $90 \%$
\end{abstract}




\title{
MENINGKATKAN PEMAHAMAN SISWA TENTANG NILAI TEMPAT MELALUI METODE DEMONSTRASI PADA SISWA KELAS II SD NEGERI NO.28 PASAR GOMPONG KECAMATAN LENGAYANG KABUPATEN PESISIR SELATAN
}

\begin{abstract}
ABSTRAK
Pendidikan merupakan suatu cara pembentukan kemampuan manusia untuk menggunakan akalfikiran/rasional mereka sebagai jawaban dalam menghadapi berbagai masalah yang timbul di masa yang akan datang. Salah satu tujuan pendidikan yaitu untuk meningkatkan kualitas sumber daya manusia. Dengan pendidikan yang baik kita akan mudah mengikuti perkembangan zaman di masa yang akan datang. Tujuan penelitian pembelajaran ini adalah untuk mengetahui apakah penggunaan metode demonstrasi dapat meningkatkan pemahaman tentang nilai tempat pada siswa kelas II SD Negeri No.28 Pasar Gompong Kecamatan Lengayang Kabupaten Pesisir Selatan. Tujuan penelitian perbaikan pembelajaran ini adalah untuk mengetahui apakah penggunaan metode demonstrasi dapat meningkatkan pemahaman tentang nilai tempat pada siswa kelas II SD

Negeri No.28 Pasar Gompong Kecamatan Lengayang Kabupaten Pesisir Selatan?

Penelitian ini mengenai peningkatan pemahaman nilai dengan menggunakan metode demonstrasi dilaksanakan melalui beberapa tahapan.Tahapan yang dimaksud adalah perencanaan, pengamatan, dan refleksi.

Hasil dari penelitian ini adalah Nampak 18 siswa telah mampu memahami materi nilai tempat melalui metode demonstrasi dan hampir seluruh siswa mengalami peningkatan yang sangat signifikan dari siklus 1 ke siklus 2 . Hal tersebut membuktikan bahwa penggunaan metode demonstrasi sangat tepat untuk meningkatkan kemampuan siswa khususnya tentang nilai tempat. peningkatan yang signifikan mulai dari pra siklus (55\%), kemudian pada siklus 1 meningkat menjadi $65 \%$ dan siklus 2 meningkat menjadi $90 \%$.
\end{abstract}

\section{Kata Kunci: metode demonstrasi}

\section{PENDAHULUAN}

Latar Belakang Masalah Pendidikan merupakan suatu cara pembentukan kemampuan manusia untuk menggunakan akalfikiran/rasional mereka sebagai jawaban dalam menghadapi berbagai masalah yang timbul di masa yang akan datang. Salah satu tujuan pendidikan yaitu untuk meningkatkan kualitas sumber daya manusia. Dengan pendidikan yang baik kita akan mudah mengikuti perkembangan zaman di masa yang akan datang. Sesuai dengan perkembangan situasi dan kondisi kehidupan, akan membawa sikap mental tingkah laku anak didik. $\mathrm{H}_{i}{ }^{\prime}{ }_{129}$ 
merupakan proses yang secara alami munculnya suatu permasalahan yang baru dalam dunia pendidikan. Sehingga dalam penyampaian materi pelajaran dituntut untuk selalu menyesuaikan dengan kondisi anak sekarang. Perlu diketahui bahwa pendidikan kemarin, sekarang dan yang akan datang banyak perubahan. Guru yang selalu menggunakan metode monoton, artinya dari tahun ke tahun tidak pernah mengalami perubahan karena adanya perubahan kondisi, mereka akan mengalami permasalahan yang yang tidak mereka sadari. Oleh karena itu sebagai seorang pendidik harus mau tahu akan kebutuhan anak didik, terutama dalam pelayanandan penyampaian materi pelajaran. Sehingga sangat perlulah sebagai pendidik mengadakan variasi metode pengajarannya. Manakah yang lebih tepat untuk menyampaikan materi supaya hasil proses belajar mengajar berhasil maksimal.Perubahan pengajaran tidak harus disertai dengan pemakaian perlengkapan uang serba hebat, tetapi lebih menekankan pada pengembangan cara-cara baru belajar yang lebih efektif dan sesuai dengan kemampuan peserta didik. Pembelajaran akan efektif bila guru dapat mengidentifikasi masalah yang dihadapi di kelasnya, kemudian menganalisa dan menentukan factor-faktor yang diduga menjadi penyebab utama, yang selanjutnya menentukan tindakan pemecahannya. Tuntutan peningkatan kualitas professional guru belum memenuhi syarat yang diinginkan atau diharapkan, karena antara petunjuk perlaksanaan yan sudah ada banyak terdapat kendala bagi para pelaksana pendidikan utamanya guru terbukti dengan dampak yang dilapangan antara lain: 1) Keterampilan anak didik masih sangat rendah, terutama tentang keterampilan. 2) Tingkat pengetahuan dan prestasi siswa dalam mata pelajaran matematika lebih rendah dari mata pelajaran yang lain. 3) Suasana belajar kurang dinamis.

Permasalahan di atas disebabkan oleh dominasi guru masih tinggi, peran guru dalam proses belajar mengajar sebagai penyebar ilmu krang berperan sebagai fasilitator, guru masih banyak bergantung pada buku, guru masih dominan menggunakan ceramah dan mencatat, guru kurang mengoptimalkan bekerja bersamansama dan siswa dianggap lulus tes atau dapat mengerjakan tes tanpa memperhatikan aspek lain seperti kejujuran,pengendalian diri, penghargaan kepada orang lain, dan kemampuan bekerja sama. Demikian gambaran situasu pembelajaran saat ini yang terjadi di lapangan khususnya pembelajaran di Sekolah Dasar. Kualitas pembelajaran dapat dilihat dari segi proses pembelajaran dari segi hasil.

Dari segi peoses pembelajaran dikatakan berhasil apabila seluruhnya atau setidak-tidaknya sebagaian besar $(75 \%)$ peserta didik terlibat secara aktif baik fisik, mental maupun social dalam proses pembelajaran di samping menunjukkan kegairahan belajar tinggi, semangat belajar yang besar dan rasa percaya diri yang tinggi. Sedangkan dari segi hasil proses pembelajaran dikatakan berhasil apabila terjadi perubahan-perubahan perilaku yang positif dari peserta didik seluruhnya atau setidak-tidaknya sebagian besar Metode mengajar banyak sekali jenisnya, disebabkan oleh karena metode ini dipengaruhi oleh beberapa factor misalnya : tujuan yang berbagai jenis dan fungsinya,tingkat kematangan siswa yang berbeda, situasi yang berbagai keadaan, pribadi guru dan kemampuan professional yang berbeda-beda. Karena itu sulit untuk memberikan satu klasifikasi yang jelas mengenai metode yang pernah dikenal di dalam pengajaran. Namun demikian ada sifat umum yang menjadi mungkin untuk mengadakan klasifikasi yang jelas tetapi fleksibel. Di dalam kenyataan banyak factor yang menyebabkan tidak selalu dapat dipergunakan metode yang paling sesuai dengan tujuan, situasi dan lain-lain.

Guru sering kali terpaksa menggunakan metode pilihan. Agar usaha pendidikan tidak siasia. Berdasarkan hasil ulangan harian ke I mata pelajaran matematika dengan kompetensi dasar "Menentukan nilai tempat satuan, puluhan dan ratusan", menunjukkan rendahnya tingkat penguasaan materi.Dari 20 siswa di kelas II hanya 11 siswa yang mencapai tingkat penguasaaan materi sebesar $75 \%$ ke atas.Oleh karena itu, peneliti meminta bantuan kepada teman sejawat untuk mengidentifikasi kekurangan dalam pembelajaran.Dari hasil diskusi tersebut, maka terungkap masalah yang terjadi dalam pembelajaran, yaitu "Rendahnya tingkat penguasaan siswa terhadap materi". Setelah penulis menganalisa dengan melakukan diskusi dan tukar pendapat dengan teman sejawat selaku pengamat, maka diketahui bahwa faktor penyebab siswa kurang menguasai materi yang diajarkan adalah: 1) Kurangnya perhatian siswa terhadap materi. 2) Guru dalam menjel crann materi terlalu cepat. 
Mengingat permasalahan tersebut adalah masalah yang bermuara dari dan dirasakan oleh guru kelas, maka peneliti berupaya mencoba cara yang paling efektif dalam memperkenalkan konsep kepada anak didik mencari yang paling mudah, dekat dengan diri siswa sehingga pelajaran Matematika menjadi menyenangkan, maka dari itu penulis mengajukan penelitian dengan judul "Meningkatkan pemahaman siswa tentang nilai tempat melalui metode demonstrasi pada siswa kelas II SD Negeri No.28 Pasar Gompong Kecamatan Lengayang Kabupaten Pesisir Selatan".

Masalah adalah segala rintangan tentang hambatan dan kesulitan yang memerlukan pemecahan jawaban agar usaha pencapaian tujuan dimaksud dapat berhasil dengan baik. Adapun rumusan masalah dalam penelitian ini adalah : "bagaimanakah penggunaan metode demonstrasi dalam meningkatkan pemahaman tentang nilai tempat pada siswa kelas II SD Negeri No.28 Pasar Gompong Kecamatan Lengayang Kabupaten Pesisir Selatan?

Tujuan penelitian perbaikan pembelajaran ini adalah untuk mengetahui apakah penggunaan metode demonstrasi dapat meningkatkan pemahaman tentang nilai tempat pada siswa kelas II SD Negeri No.28 Pasar Gompong Kecamatan Lengayang Kabupaten Pesisir Selatan?

\section{METODE PENELITIAN}

Lokasi Penelitian yang digunakan untuk melaksanakan penelitian ini adalah SD Negeri No.28 Pasar Gompong Kecamatan Lengayang Kabupaten Pesisir Selatan.Waktu yang digunakan peneliti dalam melakasanakan penelitian tindakan kelas ini selama 2 siklus, yaitu pada tanggal 13 Oktober 2016 (Siklus 1) dan 20 Oktober 2016 Mata pelajaran yang diteliti adalah Matematika dengan materi pembelajaran nilai tempat, Kelas II Semester I SD Negeri No.28 Pasar Gompong Kecamatan Lengayang Kabupaten Pesisir Selatan. Jumlah siswa SD Negeri No.28 Pasar Gompong Kecamatan Lengayang Kabupaten Pesisir Selatan kelas II B berjumlah 20 siswa. Karakteristik siswa adalagh meliputi latar belakang ekonomi yang sebagian besar siswa berasal dari keluarga kurang mampu, pendidikan orang tua pada umumnya hanya sebatas lulus Sekolah Dasar (SD).

Penelitian ini mengenai peningkatan pemahaman nilai dengan menggunakan metode demonstrasi dilaksanakan melalui beberapa tahapan.Tahapan yang dimaksud adalah perencanaan, pengamatan, dan refleksi. Tahapan tersebut dilaksanakan dalam dua siklus sebagaimana dijelaskan berikut ini: 1). Kegiatan yang dilakukan dalam tahap perencanaan pada siklus pertama ini adalah: 2). Menyusun Rencana Pembelajaran (RPP). 3) Menyiapkan media pembelajaran. 4) Menyiapkan LKS. 5) Kegiatan yang dilakukan dalam tahap pelaksanaan pada siklus pertama ini adalah: 1) Guru menjelaskan materi tentang nilai tempat ratusan, puluhan, dan satuan. 2) Siswa mencatat penjelasan guru. 3)
Guru memberi kesempatan kepada siswa untuk bertanya apabila ada kesulitan dalam memahami materi pelajaran. 4) Guru menunjuk beberapa siswa untuk mengerjakan soal di papan tulis. 5) Guru memberikan soal evaluasi kepada siswa.

Kegiatan yang dilakukan dalam tahap pengamatan pada siklus pertama ini adalah: 1 . Mengamati aktifitas siswa dalam menjawab soal. 2. Mengamati aktifitas siswa dalam kerja kelompok mengerjakan LKS. 3. Mengamati aktifitas siswa dalam menyampaikan hasil kerja kelompok. 4. Mengamati aktifitas guru dalam proses pembelajaran. 1) Kegiatan yang dilakukan dalam tahap refleksi siklus 1 ini adalah: Mancatat hasil pengamatan, Mengevaluasi hasil pengamatan, Menganalisis hasil pembelajaran dan Memperbaiki kelemahan untuk siklus berikutnya.

Adapun yang dilakukan pada siklus II adalah sebagai berikut : 1) Kegiatan yang dilakukan dalam tahap perencanaan pada siklus 2 adalah: a). Menyusun Rencana Pembelajaran (RPP) b) Memadukan hasil refleksi siklus 1 agar siklus 2 lebih efektif. c) Menyiapkan media pembelajaran. d) Menyiapkan tes tulis

Kegiatan yang dilakukan dalam tahap pelaksanaan pada siklus kedua ini adalah: Guru menjelaskan materi tentang nilai tempat ratusan, puluhan, dan satuan. Siswa mendengarkan penjelasan guru dan mengajukan pertanyaan. Guru membagi siswa menjadi beberapa kelompok. Secara berkelompok, siswa di mengerjakan LKS (menyebutkan nilai te Melalui perwakilan, tiap kelo

\section{1} . 
mempresentasikan hasil diskusi di depan kelas. Guru memberikan soal tes akhir siklus 2 . Kegiatan yang dilakukan dalam tahap pengamatan pada siklus 2 ini adalah: Mengamati aktifitas siswa dalam menjawab soal. Mengamati aktifitas siswa dalam kerja kelompok mengerjakan LKS. Mengamati aktifitas siswa dalam menyampaikan hasil kerja kelompok. Mengamati aktifitas guru dalam proses pembelajaran. Mengamati perkembangan materi. Kegiatan yang dilakukan dalam tahap refleksi siklus kedua ini adalah: Mancatat hasil pengamatan ; Mengevaluasi hasil pengamatan

\section{HASIL PENELITIAN DAN PEMBAHASAN}

Dari tindakan yang telah dilaksanakan dapat dilaporkan adanya peningkatan kemampuan mengajar pada guru dan peningkatan pemahaman nilai tempat melalui metode demonstrasi pada siswa kelas II SD Negeri No.28 Pasar Gompong Kecamatan Lengayang Kabupaten Pesisir Selatan.

Peningkatan kemampuan mengajar tersebut antara lain: Kebiasaan mengajar yang membiasakan guru aktif menjelaskan dan menerangkan mulai berkurang, dan berubah menjadi bimbnag dan mengembangkan inisiatif siswa. Kebiasaan siswa yang biasa pasif, berubah menjadi aktif dalam mengidentifikasi. Setiap akhir pelajaran, siswa memperoleh hasil belajar (produk) selama proses belajar berlangsung melalui diskusi kelompok maupun individu. Pada saat pembelajaran guru, mulai selalu memeprhatikan: Perbedaan individu. Pengorganisasian kelas. Variasi pembelajaran. Guru lebih banyak mendorong siswa berkreatif dan menciptakan iklim belajar yang kondisif. Hasil penelitian dalam proses analisis data berupa peningkatan pemahaman nilaitempat melalui metode demonstrasi pada siswa kelas II SD Negeri No.28 Pasar Gompong Kecamatan Lengayang Kabupaten Pesisir Selatan berupa tes tulis. Proses analisis data tersebut disajikan dalam 2 siklus sebagai berikut:

Berdasarkan hasil analisis data tersebut terhadap pemahaman nilai tempat, maka dapat ditentukan jumlah siswa yang mendapat nilai sama.

Secara lengkap hasil analisis data terhadap pemahaman nilai tempat siswa kelas II SD Negeri No.28 Pasar Gompong Kecamatan Lengayang Kabupaten Pesisir Selatan diuraiakan berikut ini: Siswa yang mendapat nilai 50 sebanyak 3 anak. Siswa yang mendapat nilai 60 sebanyak 5 anak. Siswa yang mendapat nilai 70 sebanyak 8 anak. Siswa yang mendapat nilai 80 sebanyak 4 anak

Untuk lebih jelasnya, hasil analisis data pemahaman nilai tempat pada siklus 1, dipaparkan berikut ini.
Hasil penelitian pada siklus 1 menunjukkan bahwa pemahaman siswa kelas II dalam memahami materi nilai tempat masih belum maksimal. Oleh karena itu, penelitian dilanjutkan pada siklus 2. Daftar nilai tersebut jika disajikan dalam bentuk grafik sebagai berikut:

Dalam proses pembelajaran siklus 2, siswa kelas II melanjutkan menjawab soal melalui tes tulis. Berdasrkan hasil analisis data terhadap pemahaman nilai tempat, maka ditentukan jumlah siswa yang mendapat nilai yang sama. Secara lengkap hasil analisis data nilai siswa kelas II SD Negeri No.28 Pasar Gompong Kecamatan Lengayang Kabupaten Pesisir Selatan diuraiakan sebagai berikut : Siswa yang mendapat nilai 50 sebanyak 0 anak. Siswa yang mendapat nilai 60 sebanyak 2 anak. Siswa yang mendapat nilai 70 sebanyak 3 anak. Siswa yang mendapat nilai 80 sebanyak 8 anak. Siswa yang mendapat nilai 90 sebanyak 4 anak

Hasil penelitian pada siklus 2 menunjukkan bahwa pemahaman siswa kelas II dalam memahami materi nilai tempat sudah banyak mengalami pengingkatan yang bermakna atau signifikan.

Daftar nilai tersebut jika disajikan dalam bentuk grafik sebagai berikut:

Berdasarkan hasil penelitian yang sudah dilaksanakan dalam siklus 1 dan 2,terlihat jelas ada peningkatan pemahaman materi nilai tempat melalui metode demonstrasi pada siswa kelas II SD Negeri No.28 Pasar Gompong Kecamatan Lengayang Kabupaten Pesisir Selatan. Peningkatan tersebut disajikan dalam tabel 4.3 berikut ini.

Berdasarkan hasil penelitian Nampak 18 siswa telah mampu memahami materi nilai tempat melalui metode demonstrasi dan hampir seluruh siswa mengalami peningkatan yang sangat signifikan dari siklus 1 ke siklus 2 rr-1 tersebut membuktikan bahwa pengg| 132 metode demonstrasi sangat tepat meningkatkan kemampuan siswa khususnya tentang nilai tempat. 
Berdasarkan data [ene;otoam di atas terlihat peningkatan yang signifikan mulai dari pra siklus (55\%), kemudian pada siklus 1 meningkat menjadi $65 \%$ dan siklus 2 meningkat menjadi $90 \%$.

\section{KESIMPULAN DAN SARAN}

Setelah adanya kegiatan perbaikan pembelajaran dapat ditarik kesimpulan sebagai. 1) Dengan menggunakan metode demonstrasi, ternyata mampu meningkatkan pemahaman tentang nilai tempat pada siswa kelas II SD Negeri No.28 Pasar Gompong Kecamatan Lengayang Kabupaten Pesisir Selatan. 2) Dengan meningkatnya pemahaman siswa kelas II SD Negeri No.28 Pasar Gompong Kecamatan Lengayang Kabupaten Pesisir Selatan pada materi tentang nilai tempat, maka prestasi siswa pun juga ikut meningkat.

Agar penelitian tindakan kelas ini bisa bermanfaat untuk sesame, maka dikemukakan saran-saran berikut ini: 1) Diharapkan agar pembaca, khususnya rekan-rekan guru melakukan penelitian lanjutan.Misalnya melakukan timdakan kelas mengenai peningkatan pemahaman siswa melalui media atau metode pembelajaran yang lain. 2) Walaupun hasil penelitian tindakan kelas ini belum tentu cocok diterapkan di lembaga pendidikan lain, peneliti tetap berharap agar hasil penelitian ini tetap dapat dilaksanakan yaitu penggunaan metode yang tepat untuk meningkatkan pemahaman nilai tempat pada siswa. Hal yang demikian perlu dilakukan, karena dengan penggunaan metode yang tepat dapat meningkatkan hasil belajar siswa. Demikian kesimpulan dan saran yang dapat disampaikan, semoga bermanfaat bagi banyak pihak.

\section{DAFTAR PUSTAKA}

Bahri, Jamara Syaiful. (2000). Keunggulan Metode Demonstrasi. Jakarta: Bina Aksara.

Cenei (1986).Tujuan Penerapan Metode Demonstrasi. Boston: Allyn \& Bacon.

Mujiono.(1986). Keterampilan Dasar Mengajar Matematika. Jakarta: Intan Pariwara.
Reuseffendi (1990).Macam-macam Metode. Jakarta: Bina Aksara.

Usman, Basyirudin. (2002). Penerapan Metode Demonstrasi dalam Pembelajaran. Jakarta: Pustaka Jaya.

Staton (1978).Penerapan Metode Demonstrasi. Boston: Allyn \& Bacon.

Winarno (1980).Pengertian Metode Demonstrasi. Jakarta: Rineka Cipta. 